\title{
Assessing the Dynamic Relationship Between Macroeconomic Factors and Stock Market Movement: Evidence from China.
}

\author{
Dzakpasu Isaac* Anita Emefa Doe \\ SILC Business School, Shanghai University, Chengzhong Road No. 20, Jiading District, Shanghai-China \\ *isaaczaps@shu.edu.cn /isaaczaps@gmail.com
}

\begin{abstract}
This paper examines short-run and long-run dynamic relationships between selected macroeconomic variables and stock prices in the China Stock Exchange proxy by Shanghai Composite Index. The data is restricted to the period for which quarterly data are available from 1992 Q1 to 2019 Q4 (112 observations) retrieved from the Federal Reserve Bank of Saint Louis, GTACSMAR database, and CEIC Database. The study employs unit root test, cointegration test, vector error correction estimates, and Innovation Accounting (impulse response test).

A Johansen-Juselius cointegration test indicates a positive long run relationship between the Chinese stock price index and exchange rate, and a negative long run relationship with the gross domestic product, and M2 money supply. An estimated vector error correction model (VECM) suggests significant unidirectional short run causal relationships between Chinese stock market returns and money supply but not for inflation. The VECM also finds a significant long run causal relationship among the macroeconomic variables in the system. The estimated speed of adjustment indicates that the Chinese stock market converges to the equilibrium within half a year.

Impulse response function analysis shows no significant relationship between China stock market returns and the macroeconomic variables. Forecast error variance decompositions suggest that $76 \%$ of the variation in Chinese stock market returns is attributable to its own shock, which implies that Chinese stock market returns are relatively independent of the macroeconomic variables in the system.
\end{abstract}

Keywords: Stock Prices, Macroeconomic Variables, Cointegration, Innovation Accounting, China.

JEL Classification: G15, E44, C58, O53

DOI: $10.7176 /$ RJFA/12-6-02

Publication date:March $31^{\text {st }} 2021$

\section{Introduction}

The recent unprecedented volatilities in stock prices have prompted the necessity to probe into numerous of questions about the relationship between the stock market returns and the rest of the macroeconomic variables such as interest rate, inflation, exchange rate, consumption, production, money supply and others. The Keynesian economic school of thought posits that the disposable income of an individual can be determined by the ratio of their consumption and saving (Investment), so this seem to suggests that the volume of assets that individual choose to hold at any point in time is constrained by the level of their income as a fundamental factor. Ralph Chami (2008) found that the level of household income is also determined by some macroeconomic variables such as wage rate, interest rate, production and a host of others which gives the basis to assume the existence of a causal relationship between some macroeconomic variables and stock prices. Cheng et al observed from a narrow spectrum that, rational investors in their dilemma sometimes ask the question such as, do the fluctuations in stock prices reflect economic factors or are they simply bubbles driven by (irrational) investor sentiment? On the other hand, do the stock price movements spill over into the rest of the economy, via consumption, investment or some other channel?

Given the importance of the stock market in the financial system of most countries, it comes as no surprise that the subject of stock market movement and macroeconomy have regularly exercised the minds of policy-makers and have been the subject of a substantial amount of empirical research. The broad question of the relationship between financial development and economic development in general has been a subject of rapidly-growing literature which has been recently surveyed (Levine, 2005).

The assessment of financial development and macroeconomy in this literature include more than just those relating to the stock market and range from assets and liabilities of banks and nonbank financial intermediaries to the size of the bond market relative to the economy as a whole, as well as stock market capitalisation and turnover variables (Groenewold et al, 2008). The focus of these literature is usually long-run in nature and employs large cross-country large database with the variables in focus measure in multi-year average to help explain the long-run nature of relationship between the variables of focus. For example, using the Arbitrage Pricing Theory (APT) developed by Ross (1976), Chen et al. (1986) used some macroeconomic variables to explain stock returns in the US stock markets. They show that industrial production, changes in risk premiums, and changes in the term structure are positively related to the expected stock returns, while both the anticipated and unanticipated inflation rates negatively relate to the expected stock returns Anokye (2008). Other researchers who studied the relationship between stock returns and macroeconomic variables in developed countries such as Japan, US, Australia, Canada and European countries (see, inter alia, (Cheung and Ng, 1998); McMillan and Humpe, 1997; Mukherjee and Naka, 
1995; Kwon and Shin, 1999; and Maysami and Koh, 2000) employ cointegration to establish a case that the relationship may run in both directions, thus from macroeconomy to the stock market or vice versa. While there are substantial findings to buttress the positive effect of Stock Prices on output, there is a mixed evidence on the sign of the effect in the opposite direction. The recent Covid-19 pandemic seems to give a clear exposure of stock market interactions and how shocks and volatility could be mitigated by triggering some potent monetary policies. For example, the China Security and Exchange Commission through the Peoples Bank of China injected close to a trillion renminbi and a further cut of its key lending rate to calm the stock market after days of turmoil. According to Bloomberg, it did so to reduce the social cost of financing to promote and support the sustainable and healthy development of the real economy. It also acted to increase the flow of money in the economy by cutting the amount of cash banks must keep in reserve, effectively freeing them to lend more cash. Over the past years, macroeconomic activity in China has seen a tremendous improvement to be classified as one of the fastest growing and robust economy whose uprising from a state of poor country to a major world economic super power is much fascinating and a classical model which the world can learn from as the People's Bank of China continues its mandate of maintaining price stability, a strong and stable exchange rate, a low inflation rate, and low interest rates. The interest rates dropped from $10.08 \%$ by the end of 1993 to $2.9 \%$ in 2019 , the Chinese yuan/dollar depreciation has relatively averaged at $7.4 \%$ in nearly a decade, as inflation rate drops from $28.40 \%$ in 1989 to an all-time low of $-0.73 \%$ in 2009 and then to $2.90 \%$ in 2019 .

In spite of overall government fiscal deficit which averages at nearly $2.70 \%$ of the GDP in the last decade, real GDP growth which has been sky rocketing has relatively averaged at nearly $6.9 \%$ to cater for growth quality and better improvement of quality of life in China. At the same time, the net foreign direct investment has been on that path of increase since its major reforms and opening up. According 2020 World Investment Report published by UNCTAD, FDI inflows continued to increase between 2018 and 2019, from USD 138 billion to 141 billion $(+2 \%)$. This growth is favoured by liberalization plans, the rapid development of the high-tech sector and the establishment of free trade zones. The stock of FDI in 2019 reached USD 1769 billion, an exponential growth when compared to 2010 when the stock was USD 587 billion. In 2019, China was ranked the world's second largest FDI recipient after United States and before Singapore. The country is the largest recipient in Asia, which significantly helps to boast it stock market capitalization and performance.

In this paper we analyse the relationship between stock market movements and macroeconomic variables in China for the period since the establishment of the Chinese Stock Market in 1990 by Mainland's benchmark Shanghai Composite Index to 2019. The study focuses on striking the balance between the short term and long-term dynamic relationship by attempting to establish a case for period prior to China's ascension to the World Trade Organization (WTO), the global financial crisis effect, and further examine the state of the same subject after it passed Japan to become the world's second largest economy.

The motivation for this research is three sided. First, the size of China's Stock Exchange. Although China remains the world's second largest economy and is mostly described as the world's factory, its stock market tied to the financial system is mostly described by analysist as quite underdeveloped (Carpenter, 2015). Despites hosting over thousands of foreign firms and ranked third position amongst the world's top ten stock exchanges and therefore, an intriguing research will help fast-track and balance the predominance of advanced economy research. Figure 1 show a graphical trend of the world's top eight country by stock market capitalization from 2003 - 2018. The data indicates that stock market capitalization for the United States and China stood at $\$ 14266.27$ billion and $\$ 512.98$ billion respective. But just in about a decade and half, stock market capitalization for both countries has grown more than one hundred percent and one thousand percent quantified at $\$ 30436.31$ and $\$ 6324.88$ respectively. Despite a remarkable and sporadic expansion to China's stock market capitalization, it still remains a pie of countries like the United States, Japan, and United Kingdom

Figure 1: Global stock market capitalization trend (2003 - 2018)

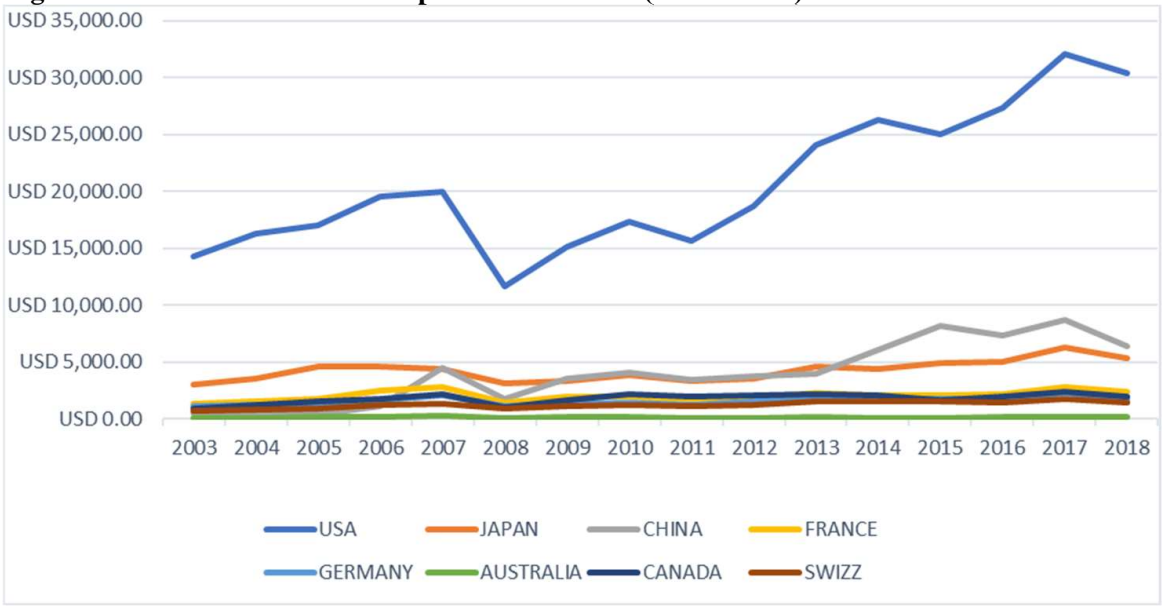

Data source: Own calculations based on https://www.theglobaleconomy.com 
Figure 2: Global stock market capitalization for 2018

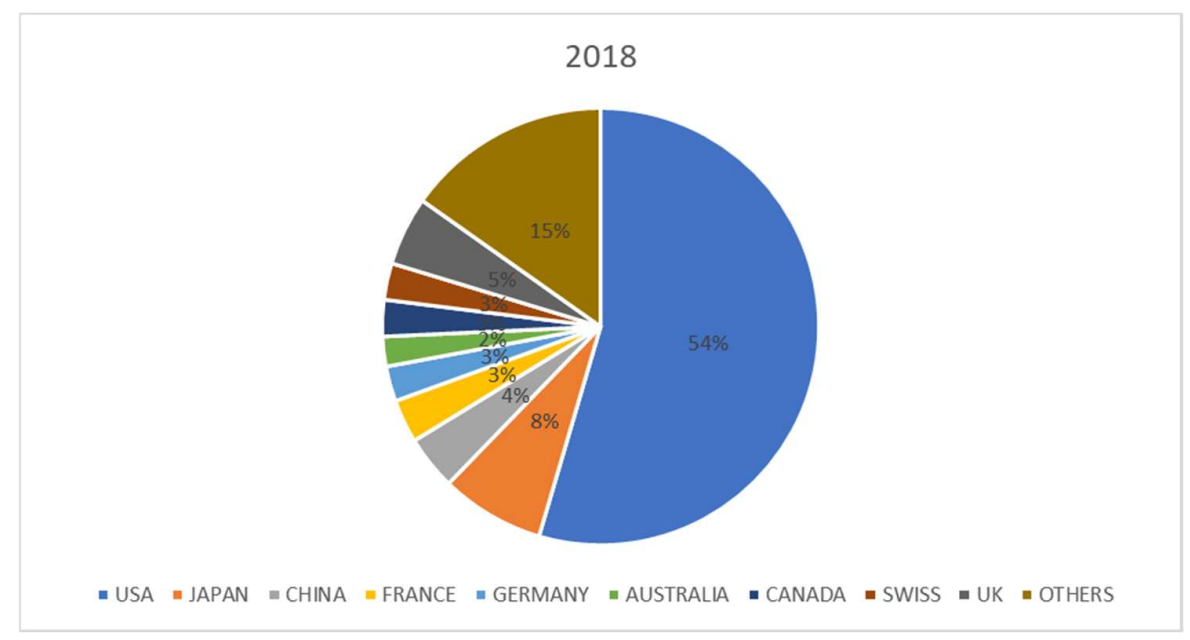

Data source: Own calculations based on https://www.theglobaleconomy.com

Secondly, the relationship between output, inflation and stock prices is not clear; in particular, negative effects of output shocks on stock prices have been reported in several papers such as Lee (1992) for the US, Cheung and $\mathrm{Ng}$ (1998) for a set of five countries and Groenewold (2003) for Australia. This is in contrast to other findings such as those by Padhan (2007) and seems counterintuitive although Groenewold (2008) suggests an explanation which distinguishes demand- from supply-driven output shocks. Analysis of this relationship for different countries will provide more information on this important connection.

Thirdly, the macroeconomic factors and stock price macroeconomy nexus literature on China seems to be few if not lucking Groenewold (2008). Most of these publications are authored in Mandarin which sometimes limit reader friendliness to English speakers. Most recent works which also discussed this subject in the context of China are Liu and Sinclair (2008), second Groenewald et al. (2009) who researched the subject without giving much focus to factors such as Inflation rate, Exchange rate, and Interest rate which this research have captured in details as benchmark for case analysis.

This present study uncovered the fact that there exists a long-run equilibrium relationship between macroeconomic variables and stock prices in the Chinese stock market, and the lagged and two-lagged period of stock prices has negative influence on current period while the lagged and three lagged period of Gross Domestic Product also shows a significant but negative influence on current period. This may prompt investors not to base their expectations of future results on past performance because the likelihood of various stock price outcomes is hypothetical in nature and everybody should realize about the ups and downs of stock market. Also, Inflation (CPI) is negatively related to stock prices in China in the short-run with a significant coefficient of -0.027 . This means that the system corrects its previous period disequilibrium 0.027 times reflecting a less sizable speed of adjustment to reach equilibrium steady state position. A similar study for China by Zhongqiang (2014) also substantiates this outcome that inflation is weakly related to stock prices in China but its insidious effect on macro economy is evident because raising inflation surges the cost of production, and consumers can purchase fewer goods due to reduction in purchasing power, firms' revenues and profits decline resulting in firms' value and stock prices.

\section{Literature Review.}

\subsection{Stock Returns and Macroeconomic Variable}

The Dividend Discount Model (DDM) developed by Miller Modigliani (1960), could be said to have lucidly explain the relationship between stock prices and macroeconomic factors better than any other theoretical stock valuation model. According to the DDM, the current price of a company's equity share is equivalent to the sum of all of its future dividend payments, discounted back to their present value. Thus, the key determinant of a share price is the required rate of return (RRR) and the expected future cash flow. (see Tessaromatis, 2003; Gan et al 2006; Humpe and Mcmillan, 2007) suggesting that economic factors that influence the expected future cash flow and required rate of return affect the share price. Beltratti, et, al (2002) investigated the relationship between the stock market volatility and macroeconomic variables using S\&P500 data for the period from 1990 to 2012. Macroeconomic fundamentals were money supply, interest rate, inflation and industrial production. They employed GARCH and structural breaks to found a weak evidence of long memory in volatility once structural change is accounted for and a dual relationship between stock market and macroeconomic instability: macroeconomic volatility explains the persistent dynamics in stock market volatility, while stock market volatility has significant but shortlived effects on output and inflation volatility.

In another study to investigate the relationship between real aggregate economic activity and real stock prices from the Australian market using Johansen Multivariate Cointegration methodology, Chaudhuri and Smiles (2004) confirmed that real stock return in Australia was correlated to short-term departures from the long-run relationship and vary in real 
macroeconomic activity. They also highlighted that the information provided by the cointegration contains some additional information that was not already present in other sources of return variations such as future GDP growth, term spread, or impacts on term covered.

From multi-factor Abtrage Pricing Theory (APT) approach, Hamao (1988) argued that inflation had a significant effect on the Japanese Stock market returns. Unlike Rapach (2002) who argues that increase in inflation does not result in persistent depreciation of share real value, Fama et al. in their investigation of the relationships between stock prices and real activity, inflation, and money discovered a strong positive correlation between common stock returns and real variables. The exchange rate which indicates the rate at which a country's' currency is exchanged for another nation or economic zones currency, has been argued fairly to affects stock prices in a way similar to the inflation variable. Depreciation of the local currency makes import expensive compared to export, leading to increased production cost of import companies. Since all the cost cannot be passed on to the consumer due to the competitiveness of the market, corporate earnings, which are a determinant of stock prices according to the DDM, fall. Bloomberg reported in August 1, 2019 that, the Peoples' Bank of China set the yuan's daily reference rate below 7 per dollar for the first time in over a decade. This, in response to new tariffs of $10 \%$ on $\$ 300$ billion worth of Chinese imports imposed by the Trump administration, and was set to go into effect September $1 \mathrm{st}, 2019$. The Global markets sold off on the move, including in the U.S. where the DJIA lost $2.9 \%$ in its worst day of 2019 . This emphasizes the shocks of exchange rate and market activities. Although, Solnik (1997) proved that exchange rate is a nonsignificant factor in explaining development of stock prices, Jorion (1990) finds some relationship between stock returns of US multinational companies and the effective US dollar exchange rate.

With reference to the DDM, an inverse relationship between interest rate and share price is usually identified, although it has been argued that an increase in the interest rate or discount by the central bank may not have a direct effect on the stock market but the ripple effect of dynamic relationship between Banks versus customers and companies' borrowing rate is firmly established. Gan et al (2006) ague that opportunity costs of holding cash rises with increase in interest rate, and the trade-off to holding other interest-bearing securities would lead to a decrease in share price. Empirically, Kuang-Liang Chang (2009), employed GJR-GARCH model using interest rate, dividend yield, and default premium to establish a case that macroeconomic variables can affect the stock return dynamics through two different channels, and the magnitude of their influences on returns and volatility is not constant. However, the effects of the three macroeconomic variables on returns are not time-invariants but are closely related to stock market fluctuations.

Finally, Groenewald et al. (2009), also obtained similar results applying the Johansen cointegration within the Vector Error Correction Model (VECM) which examined the relationship between stock market development and economic growth for China which is also relevant for this present study. Their analysis covered the period 1990 to 2008 using two variables thus, gross domestic product (GDP) and Shanghai Composite Stock Index. Their results indicate that there is strong evidence of long-run causality from the economy to the stock market but not vice versa. They also find modest but weaker evidence of a similar short-run effect. Although their results are realistic, it seems to contradiction the above discussed literature since most of the findings indicated that in the short run, the stock market takes the lead until the feedback mechanism take effect. Also, their use of Gross Domestic Product as proxy for growth can be criticised as GDP alone can't be a good proxy for economic growth.

We conclude this section by establishing a case on the limited literature on stock market and macroeconomic nexus in China. Groenewald (2008) cited that in the Chinese Language Literature, there are several papers which deal with subject of this paper although there appears to be some confusion between output and growth. With several papers claiming the assessment of stock prices and economic growth but actually analysing the relationship between stock prices and GDP without considering other major economic variables like Interest rate, exchange rate, Inflation rate which tends to have significant influence on business activities and hence the likelihood of firm's profitability which is also significant to share prices, are being relegated. Nevertheless, those studied still remain important as relevant literature for the subject of this paper. Examples are: Ran, Zhang and Wu (2003), Ran, Hu and Wang (2005), Liang and Teng (2005) and Fan (2006). These papers generally test for stationarity and cointegration in the (logs of) stock prices and macro variables, principally output, and then go on to test for causality between them. Some recent papers including Han, Zhang and Wu (2008), delineate from previous modus by tackling inflation and stock prices and decomposes inflation shocks into supply and demand-driven ones which, it is found, have different effects on stock prices.

Finally, two English-language papers are also related to this present study, the first by Liu and Sinclair (2008), second Groenewald et al. (2009). The former analyses the relationship between stock market and economic growth for (Hongkong, Taiwan and Mainland China) by analysing the relationship between the log of stock prices and the log of output in a Vector Error Correction Model framework. But interestingly they find a strong evidence of short-run causality running from stock prices to output but not vice versa but claim that output affects stock prices in the long run and this contradicts the findings of the later which also documented findings of modest but weaker evidence of short-run causality from economy to stock market and a strong evidence of long-run causality from the economy to the stock market but not vice versa.

\subsection{Research Hypothesis and Justification.}

Based on the aforementioned literature, macroeconomic variables and exchange rates are likely related to stock prices. This study includes Gross Domestic Product (GDP), money supply (M2), inflation (consumer price index), and foreign exchange rates. Accordingly, the following hypotheses are considered:

Shanghai Composite Index (SSE): The SSE Composite, is a market composite made up of all the A-shares and B-shares that trade on the Shanghai Stock Exchange. This variable will serve as the dependent variable in this analysis since it captures the performance of the market and it is the dependent variable in regression analysis. The index is calculated by using a base period of 100 . The first day of reporting was July 15,1991 . Its selection is motivated by data availability. With reference to empirical 

in China

Money Supply (M2): M2 is a measure of the money supply that includes all elements of M1 as well as "near money." M1 includes cash and checking deposits, while near money refers to savings deposits, money market securities, mutual funds and other time deposits. These assets are less liquid than M1 and not as suitable as exchange mediums, but they can be quickly converted into cash or checking deposits. This study hypothesizes that Money supply (M2) is related to stock prices in the shortrun.

Inflation: the sporadic increase in prices of goods and services results in high cost of living and reduces the purchasing power of currency. Rising inflation has an insidious effect thus, input prices soar higher, consumers can purchase fewer goods, revenues, and profits decline making households to shift resources from investments to consumption. This leads to a fall in the demand for market instruments and subsequently leads to a reduction in the volume of stock traded. Anokye and Tweneboah (2008) documented that, the government monetary policy responds to the increase in the rate of inflation with economic tightening policies, which in turn increases the nominal risk-free rate and hence raises the discount rate in the valuation model. Also, DeFina (1991) argues that nominal contracts that disallow the immediate adjustment of the firm's revenues and costs prevent cash flow to grow at the same rate as inflation. And so, we hypothesized that in the short run there is a negative relationship between inflation and stock price in China.

Exchange rate: the value at which one countries currency is exchange for another affects the stock market in similar way as inflation. China is the second largest economy in the world and its exports dominates its import, coupled with the fact Renminbi usually perks below other major currency pairs makes trade attractive to export dominated companies whiles the import dominated firms will experience increase in production cost. Historical performance of the Renminbi against the US dollar makes Chinas exports attractive and also gains competitive advantage in the international markets. A weaker currency also makes China's imports costlier, thus spurring the production of substitute products at home to aid the domestic industry. Therefore, this study hypothesizes a ripple positive effect on the performance of SSE Composite Index in the short-run. Exchange rate movements frequently focus on changes in credit market conditions, reflected by changes in interest rate differentials across countries, and changes in the monetary policies of central banks. The profit-maximizing investors in an efficient market will ensure that all the relevant information currently known about changes in macroeconomic variables are fully reflected in current stock prices, so that investors will not be able to earn abnormal profit through prediction of the future stock market movements (Chong and Koh, 2003). The conclusions drawn from the efficient market hypothesis (EMH) includes early studies by Fama and Schwert (1977), Nelson (1977), and Jaffe and Mandelker (1976), all affirming that macroeconomic variables influence stock returns.

Gross Domestic Product: which has been used as theoretical measure of the worth of goods and services within a particular jurisdiction is mostly been used to measure the worth and robustness of an economy. Competitive GDP figures tend to paint an image of prosperous economy as in the case of Chinas' double-digit GDP over the years and hence it is anticipated the GDP will have a significant positive influence on stock performance most notably in the Short run

\section{Methodology \\ 3.1 Data Source}

This section describes the data and outlines the methodology used in the selection of indicators. The sample is restricted to the period for which quarterly data are available, which is from 1992:1 to 2019:4 (112 observations). The study made use of Shanghai Composite Index (SSE), Consumer Price Index (CPI) proxy for inflation, Exchange rate (ER), Money Supply (M2), and Gross Domestic Product (GDP). The start of the sample being motivated by the availability of stock price data. Since the data for the major macroeconomic variables are made available on quarterly basis, the study employed quarterly analysis since it has the tendency to explain the degree of fast dynamic interaction between the variables when juxtaposed with annual frequencies. The data on SSE Index were obtained from GTA-CSMAR database. Data in this database are reported on a daily basis and were averaged over the quarter to obtain quarterly observations. Averaging over the quarter removes very high frequency movements in stock prices which are hardly likely to respond to GDP variations (or vice versa). All the other data on macroeconomy was obtained from the Federal Reserve Bank of St. Louis (FRED) database, while GDP data was obtained from CEIC database, Money Supply was also obtained from GTA-CSMAR database. Neither series was seasonally adjusted. This was particularly obvious for the GDP data which has strong seasonal fluctuations. The study experimented with various methods of seasonal adjustment for the GDP data, some of which were clearly unsatisfactory since there remained distinct seasonal movements in some years

\subsection{Estimation Analysis}

The principal method employed to analyse the time series behaviour of the data involves cointegration and the estimation of a Vector Error Correction Model (VECM). Specifically, the Johansen maximum likelihood procedure. This technique has been well popularized for testing the long-run relationships among variables since it permits more than one cointegrating relationship so is more generally applicable than the Engle Granger test which is based on the Dickey-Fuller (or the augmented) test for unit roots in the residuals from a single (estimated) cointegrating relationship. In estimating the cointegration the study foremost considered whether each of the series is integrated of the same order. To do this the standard Augmented Dickey-Fuller test and Phillips-Perrons unit root tests was employed. The number of cointegration ranks ( $r$ ) was tested with the maximum eigenvalue and trace test. From the above theoretical, intuitive, and empirical discussion, the relationship between stock prices and selected macroeconomic variables as described above can be postulated as follows: 
SSEIDX $_{t}=\beta_{0}+\beta_{1} C P I_{t}+\beta_{2} E X_{t}+\beta_{3} G D P_{t}+\beta_{4} M 2_{t}+\xi_{t}$

Where $\beta_{0}$ is a constant, $\beta_{1} \ldots \ldots \ldots \ldots \ldots \ldots \ldots \ldots \ldots \ldots \beta_{4}$, are the measure of sensitivity for each of the macroeconomic variable to stock price and $\xi_{t}$ is a stationary error correction term.

\subsection{Empirical Analysis}

\subsection{Descriptive Statistics of Data}

Table 1 displays a summary of descriptive statistics of the variable. Sample mean, standard deviation, skewness and kurtosis, and the Jerque Berra statistic and $p$-value have been reported. The high standard deviation of SSEIDX with respect to the mean is an indication of high volatility in the stock market. From the p-values, the null hypothesis that CPI, EX, GDP and M2 are normally distributed at $5 \%$ level of significance cannot be rejected.

Figure 3: Stock price, inflation, exchange rate, gross domestic product and money supply in China.

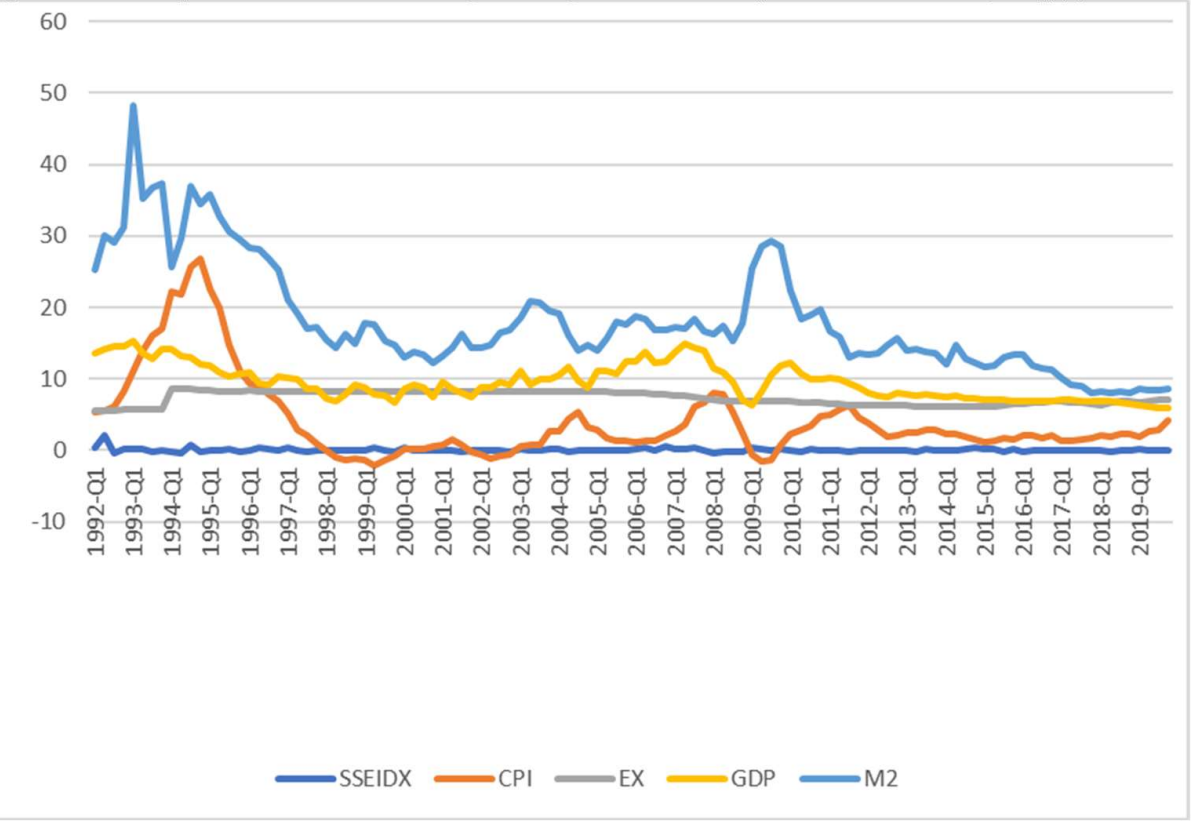

Source: own calculations based on GTA-CSMAR, CEIC and FRED database

Table 1. Descriptive Statistics of SSEIDX and Macroeconomic Variables (Quarterly, 1992-2019)

\begin{tabular}{|l|l|l|l|l|l|}
\hline & SSEIDX & CPI & EX & GDP & M2 \\
\hline Mean & 0.043 & 4.131 & 7.328 & 9.564 & 18.247 \\
\hline Std. Dev. & 0.266 & 5.826 & 0.963 & 2.474 & 7.826 \\
\hline Skewness & 4.476 & 2.184 & -0.227 & 0.579 & 1.26 \\
\hline Kurtosis & 34.948 & 7.606 & 1.535 & 2.273 & 4.381 \\
\hline Jarque-Berra & 5136.938 & 188,063 & 10.968 & 8.732 & 38.158 \\
\hline Probability & 0.000 & 0.000 & 0.004 & 0.013 & 0.000 \\
\hline Minimum & -0.415 & -2.06 & 5.462 & 6.000 & 8.000 \\
\hline Maximum & 2.122 & 26.9 & 8.708 & 15.3 & 48.34 \\
\hline Obs. & 112 & 112 & 112 & 112 & 112 \\
\hline
\end{tabular}

\subsection{Unit Root Test}

It is well known in the literature that the data generating process for many economic variables are characterized by stochastic trends that might result in spurious inference if the time series properties are not carefully investigated. A time series is said to be stationary if the mean and autocovariances of the series do not depend on time. Any series that is not stationary is said to be non-stationary (i.e., it has a unit root). Therefore, to determine the order of integration and stationarity of the variables, Augmented Dickey-Fuller (ADF) (Dickey \& Fuller, 1979, 1981), and Phillips-Perron (PP) unit root tests (Phillips \& Perron, 1988 ) were used. Granger causality or non-causality is concerned with whether lagged value of one variable (e.g., "X") do or not do improve on explanation of another variable ("Y") obtainable from only lagged values of "Y" (Granger, 1969). We must note that the statement " $X$ " Granger cause " $Y$ " does not imply that " $Y$ " is the effect or the result of "X". Granger causality measures precedence and information content but does not indicate causality in the more common use of the term. Granger causality test is based on following two equations: 


$$
\begin{aligned}
& Y_{t}=\alpha_{y 0}+\sum_{i=1}^{K} \beta_{i} Y_{t-1}+\sum_{j=1}^{k} \gamma_{j} X_{t-j}+\varepsilon_{t} \\
& X_{t}=\alpha_{x 0}+\sum_{i=1}^{K} \beta_{i} X_{t-1}+\sum_{j=1}^{k} \gamma_{j} Y_{t-j}+u_{t}
\end{aligned}
$$

The reported F-statistics are the Wald statistics for the joint hypothesis

$$
\gamma_{j}=0 \quad\left(\gamma_{1}=\gamma_{2}=\gamma_{3}=\ldots \gamma_{k}=0\right)
$$

In common tests, the null hypothesis is that " $X$ " does not Granger-cause " $Y$ " (in the first regression) and that " $Y$ " does not Granger-cause " $X$ " (in the second regression). A lag length (from " $i, j$ " to " $K$ ") corresponds to relevancy, to reasonable beliefs about the longest time over which one of the variables could help predict the other

Table 3 reports the results of unit root tests. All test equations were tested by the method of least squares, including an intercept, but no time trend in the model. Probabilities for all tests assume asymptotic normality. In the ADF and PP tests, an optimal lag in the tests is automatically selected based on Hannan-Quinn information criterion. in the tests is automatically selected based on the Newey-West estimator (Newey \& West, 1994) using the Bartlett kernel function. In ADF and PP tests, probability values for rejection of the null hypothesis of a unit root are employed at the 0.05 level based on MacKinnon (1996) one-sided p-values. Both results indicate that all the data are non-stationary at levels but first differences are stationary at 5\% significant level. Consistent with Figure 3, and further analysis from ADF and Figure 4, the study concludes that all the variables are I (1).

\section{Table 2. Results of Unit Root Tests}

\begin{tabular}{|l|l|l|l|l|}
\hline Tests & ADF (0) & ADF (1) & PP (0) & PP (1) \\
\hline SSEIDX & -11.029 & $-23.129^{* *}$ & -114.402 & $-116.300^{* *}$ \\
\hline CPI & -1.300 & $-5.578^{* *}$ & -8.620 & $-52.401^{* *}$ \\
\hline EX & -2.197 & $-10.202^{* *}$ & -7.231 & $-106.397^{* *}$ \\
\hline GDP & -2.089 & $-10.101^{* *}$ & -6.588 & $-94.933^{* *}$ \\
\hline M2 & -1.982 & $-12.469^{* *}$ & -16.293 & $-119.194^{* *}$ \\
\hline
\end{tabular}

Note: The numeric values in cells are t-statistic. Probability values for rejection of the null hypothesis are employed at the $5 \%$ significant level $(*$, p-value $<0.05$ and $* *$, p-value $<0.01)$

\section{Figure 4: Stationarity test for Macroeconomic Variables and Stock Prices}

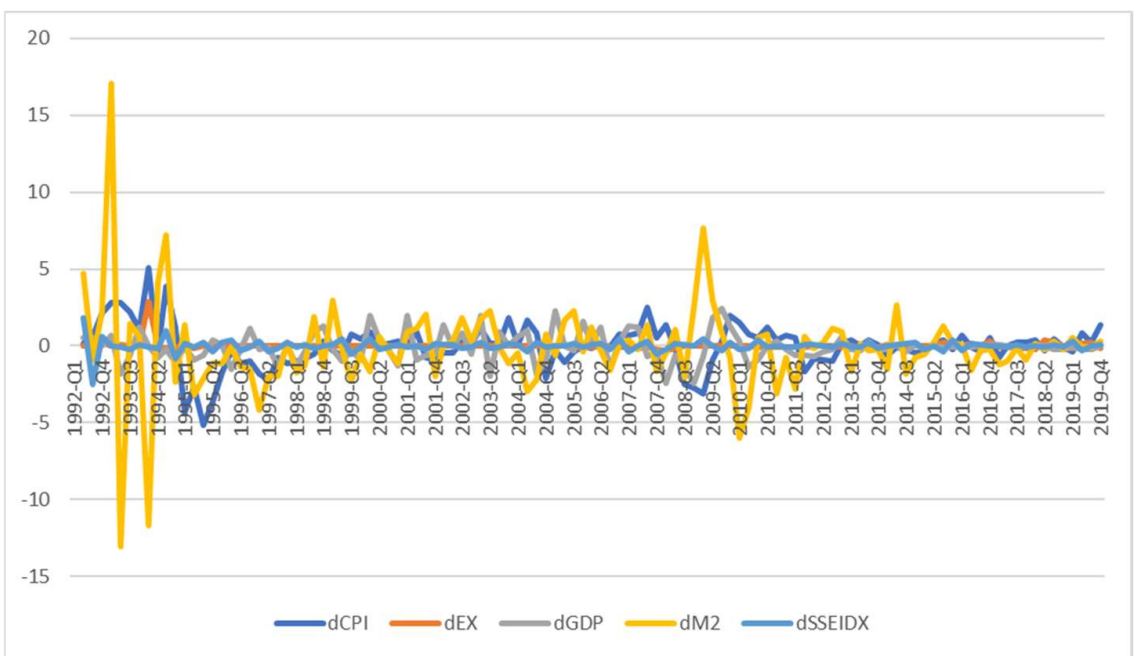

Source: own calculations based on GTA-CSMAR, CEIC and FRED database

\subsection{Cointegration Test}

There are two test methods to identify whether there is a long-run relationship among variables: The Engle-Granger single equation test method (Engle \& Granger, 1987) and the Johansen cointegration test (Johansen, 1988). Anokye and Tweneboah (2008) report that the Johansen approach is more efficient than the Engle-Granger single equation test method because the maximum likelihood procedure has useful large and finite sample properties. The Johansen cointegration test models each variable as a function of all the lagged endogenous variables in the system. In addition, the procedure uses two ratio tests: a trace test and a maximum eigenvalue test, to test the number of cointegration relationships. Both tests can be used to determine the number of cointegrating vectors present, although they do not always indicate the same number of cointegrating vectors. If trace statistics and maximum eigenvalue statistics yield different results, the result of the maximum eigenvalue test is preferred due to the benefit of carrying out separate tests on each eigenvalue. The optimal lag length was determined by Akaike Information Criterion (AIC) using 8 maximum lags in the general VAR model. The aim is to choose the number of parameters, 
which minimizes the value of the information criteria. The SIC has the tendency to underestimate the lag order, while adding more lags increases the penalty for the loss of degrees of freedom. To make sure that there is no remaining autocorrelation in the VAR model, AIC is selected as the leading indicator. The model lag length reported in Table 4 indicates appropriate lag length of 4 for AIC.

Table 3: Optimum lag length selection criterion

\begin{tabular}{|l|l|l|l|l|l|}
\hline Lag & LR & FPE & AIC & HQIC & SBIC \\
\hline 0 & & 37.9961 & 17.8269 & 17.8784 & 17.954 \\
\hline 1 & 912.33 & .009528 & 9.53525 & 9.84428 & $10.2981^{*}$ \\
\hline 2 & 76.09 & .007439 & 9.28439 & 9.85095 & 10.6829 \\
\hline 3 & 106.98 & .004337 & 8.73652 & 9.56061 & 10.7707 \\
\hline 4 & 110.61 & $.00246^{*}$ & $8.15375^{*}$ & $9.23537^{*}$ & 10.8236 \\
\hline 5 & 74.188 & .002001 & 7.92116 & 9.26032 & 11.2267 \\
\hline 6 & 47.19 & 7.94819 & 9.54486 & 11.8893 \\
\hline 7 & 98.037 & .001424 & 7.48629 & 9.3405 & 12.0631 \\
\hline 8 & $60.804 *$ & 7.38241 & 9.49415 & 12.5949 \\
\hline$*$ indicates lag order selected by the criterion & .001386 & & \\
\hline LR: Sequential modified LR test statistic (each test at 5\% level) & & \\
\hline FPE: Final prediction error & & & \\
\hline AIC: Akaike information criterion & & \\
\hline SBIC: Schwarz information criterion \\
\hline \multicolumn{7}{|l|}{ HQIC: Hannan-Quinn information criterion } & \\
\hline
\end{tabular}

Table 4 presents the results of the Johansen cointegration test. The test equation was tested by the method of least squares. The regression model allows for a linear deterministic trend in the data and includes an intercept, but no trend in vector autoregressive models. Lag interval in first differences is 1 to 4 . For the two likelihood ratio test statistics, the probability value for rejection of the null hypothesis of no cointegration is based on the MacKinnon, Haug and Michelis (1999) p-values. The null hypothesis of no cointegration is rejected at the $5 \%$ significance level. Both the trace and the maximum eigenvalue tests indicate that at least three cointegrating equations exist at the 0.05 level. Therefore, the null hypothesis of no cointegration can be rejected at the 0.05 level. Considering the results of the Johansen cointegration test in Table 4 , this study supports hypothesis 1 that there is a long-run equilibrium relationship between stock prices and macroeconomic variables in China

Table 4. Results of Johansen Cointegration Test

\begin{tabular}{|l|l|l|}
\hline Maximum rank & Trace Statistic & Maximum eigenvalue \\
\hline 0 & $172.1136(68.52)$ & $114.9131(33.46)$ \\
\hline 1 & $57.2005(47.21)$ & $24.5075(27.07)$ \\
\hline 2 & $32.6930(29.68)$ & $17.9055(20.97)$ \\
\hline 3 & $14.7875(15.41)^{*}$ & $13.6185(14.07) *$ \\
\hline 4 & $1.1690(3.76)$ & $1.1690(3.76)$ \\
\hline
\end{tabular}

Note: Regression model: SSEIDX = CPI + EX + GDP + M2. The values in parenthesis / brackets are critical values at the 0.05 level. Cointegrating equations are significant at the 0.05 level $\left(*\right.$, p-value $<0.05$ and ${ }^{* *}$, p-value $\left.<0.01\right)$.

\subsection{Vector Error Correction Model}

Considering the results of the Johansen cointegration test in Table 4, it is evident that there is a long-run equilibrium relationship between stock prices and macroeconomic variables in China. In this case, an unrestricted vector autoregressive model (VAR) would not be an effective option for testing short-run dynamics. Engle and Granger (1987) noted that if two or more variables are cointegrated, there is always a corresponding error correction representation in which the short-run dynamics of the variables in the system are influenced by the deviation from equilibrium. The cointegrated variables must have an error correction representation in which an error correction term is incorporated into the model. In this case, a vector error correction 
model is formulated to reintroduce the information lost in the differencing process, thereby allowing for long-run equilibrium as well as short-run dynamics. The vector error correction model (VECM) implies that changes in one variable are a function of the level of disequilibrium in the cointegrating relationship (captured by the error correction term), as well as changes in other explanatory variables. Thus, the vector error correction model is useful for detecting the long-run and short-run elasticity when the variables are cointegrated.

The VECM is a technique that facilitates the capture of both the dynamic and interdependent relationships of the particular variables and is a special type of restricted VAR which can correct a disequilibrium that may shock the whole system. The VECM can distinguish between the short-run and long-run elasticity because it can capture both the short-run and the longrun dynamics. The long-run dynamics are determined by the error correction term. The long-run elasticity is implied by the significance of the t-test of the lagged error correction terms. The multivariate vector error correction model provides t-statistics that are used to interpret the statistical significance of coefficients of the regressors.

Statistical inference is sensitive to parameter instability, serial correlation in residuals and residual skewness. The results of VECM estimates, model diagnostic tests and residual diagnostic tests indicate that there are considerably fewer outliers and the fluctuation bands are smaller. Skewness of the series is not significantly different from a normal distribution. Histogram normality using the Jarque- Bera test (null hypothesis: residuals are multivariate normal) is rejected. BreuschGodfrey serial correlation Lagrange multiplier or LM test (null hypothesis: no serial correlation at lag order 4) is rejected. Heteroskedasticity test (null hypothesis: no autoregressive conditional heteroskedasticity or ARCH effect at lag order 1) is also rejected. Thus, this model yields acceptable results.

Table 5 reports the results of VECM estimates. The significance of ECT(t-1) indicates the lagged structure of ECT is stable, and thus, justifies long-run dynamics. In testing hypothesis 2 that money supply(M2) is related to stock prices in the short-run, Table 5 shows that M2 is not significant at the 0.05 level in China, this finding does not delineate from the findings of Tantatape and Jung (2018) who conducted their research in Korea. Wang (2016), after digesting the subject of Money supply and Stock Prices in China discovered that the direction and speed of adjustment towards the long-run equilibrium path equilibrium, coefficient of adjustment of the money supply will be -0.036 , and the stock prices from a non-equilibrium state will be back to equilibrium very slightly. Which further indicated that money supply does not significantly affect stock prices in China. hypothesis 3 states that Inflation (CPI) is related to stock prices in the short-run. It is evident that CPI is negatively but not significantly related to stock prices in China.

Furthermore, with respect to hypothesis 4 that exchange rate is positively related to stock prices in the short-run, the estimated model reveals that exchange rate (Chinese Yuan/USD) is positively and significantly related to stock prices in the short-run at 0.01 and 0.10 level, notably at the lagged order of two and four. This finding is consistent and accurate owing to the fact that China's has strategically positioned itself to becomes the world's largest exporting country and hence it has consolidated all effort to calibrate the growth of its domestic industries to power its domestic consumption there by limiting excessive importation. According to hypothesis 5 that short-term dynamic interaction between Stock prices and Gross Domestic Product is expected to be positive but contrary to the findings of the research it is evident that the relationship between GDP and stock prices in china is negative highly significant at the 5\% and $10 \%$ significant levels and more notably the second and fourth quarters respectively. Further analysis of the impact of GDP on stock prices shows that the variations in the stock prices can well explains the variations in the GDP of which all are significant at the $5 \%$ level.

\section{Innovation Accounting (Impulse Responses)}

The cointegration analysis only captures the long-run relationship among the variables. Since it does not provide information on responses of variables to shocks or innovations in other variables, the study employed the Impulse Response Function and Forecast Error Variance Decomposition based on the VECM to examine how SSEIDX responds to shocks in the other variables. Figure 5 shows the impulse response functions while the variance decomposition at the $5 \%$ significance level is presented in Table 6 . A shock to the $j$-th variable not only directly affects that variable but is also transmitted to all of the other endogenous variables through the dynamic (lag) structure of the vector autoregressive. The effects of the shocks on the endogenous variables can be assessed by estimating impulse responses and variance decomposition functions. An impulse response function traces the effect of a one-time shock to one of the innovations on current and future values of the endogenous variables. Since innovations are usually correlated, it may be viewed as having a common component that cannot be associated with a specific variable. In order to interpret the impulses, it is common to apply a transformation to the innovations that cause them to become uncorrelated. The Cholesky transforming method uses the inverse of the Cholesky factor of the residual covariance matrix to orthogonalize the impulses. This method imposes an ordering of the variables in the vector autoregressive and attributes all of the effect of any common component to the variable that comes first in the vector autoregressive system. For stationary vector autoregressive models, the impulse responses should die out to zero and the accumulated responses should be asymptote to some constant.

Figure 5 presents the results of the impulse responses of stock prices to Cholesky one standard deviation innovations of the endogenous variables: stock price (SSEIDX), consumer price index (CPI), exchange rate (EX), gross domestic product (GDP) and money supply (M2). The response of stock prices itself to each shock shows a positive and permanent impact throughout with a sharp decrease in the first five quarters and assumes stability by the eight quarter. This could possibly be evidence of the high volatilities that the Shanghai composite index faced in the early years of the establishment of the Shanghai stock exchange. Although, the response of stock prices to consumer price index shows a sharp negative impact at the early stage and reaches an all-time low by the third quarter and steadily approached stability fifteenth quarter. The influence of stock prices on exchange rates (RMB USD) in the short run is unstable by showing a sharp positive trend in the first two quarters and drops quickly to equilibrium by five quarters and steadily balances off in the zero zone in the long run. Hence, these results indicate that China's stock prices are largely determined by its own shock and exchange rate shock. The responses of stock prices to shocks of gross domestic product is initially positive but absorbs huge shock by the fourth quarter, before quickly 
reaching equilibrium by the tenth quarter. Finally, the response of stock prices to money supply is the short run is negative and unstable until a steady state equilibrium is attained by the seventh quarter where the shocks are fully absorbed into equilibrium.

Table 5: Results of Vector Error Correction Estimate for SSEIDX

\begin{tabular}{|c|c|c|c|c|c|}
\hline Dynamics & $\begin{array}{l}\text { Dependent Variable: } \\
\text { SSE(t) } \\
\text { Lag Order in }()\end{array}$ & Coefficient & $\begin{array}{l}\text { Standard error } \\
\text { in } 0\end{array}$ & $\begin{array}{l}\text { t-statistic } \\
\text { in [] }\end{array}$ & p-value \\
\hline & Cointegrating $\mathrm{ECT}_{\mathrm{t}-1}$ & -0.478 & 0.123 & -3.900 & $0.000 * * *$ \\
\hline \multirow{20}{*}{$\begin{array}{l}\text { Short run } \\
\text { Dynamics }\end{array}$} & SSEIDX $_{\mathrm{t}-1}$ & -0.391 & 0.126 & -3.09 & $0.002 * * *$ \\
\hline & SSEIDX $_{\mathrm{t}-2}$ & -0.345 & 0.123 & -2.80 & $0.005 * * *$ \\
\hline & SSEIDX $_{\mathrm{t}-3}$ & -0.056 & 0.092 & -0.60 & 0.546 \\
\hline & SSEIDX $_{\mathrm{t}-4}$ & 0.035 & 0.084 & 0.41 & 0.679 \\
\hline & $\mathrm{CPI}_{\mathrm{t}-1}$ & -0.027 & 0.020 & -1.35 & 0.345 \\
\hline & $\mathrm{CPI}_{\mathrm{t}-2}$ & -0.023 & 0.021 & -1.07 & 0.665 \\
\hline & $\mathrm{CPI}_{\mathrm{t}-3}$ & -0.017 & 0.018 & -0.91 & 0.366 \\
\hline & $\mathrm{CPI}_{\mathrm{t}-4}$ & -0.001 & 0.016 & -0.06 & 0.951 \\
\hline & $\mathrm{GDP}_{\mathrm{t}-1}$ & -0.040 & 0.021 & -1.92 & $0.055^{*}$ \\
\hline & $\mathrm{GDP}_{\mathrm{t}-2}$ & -0.009 & 0.021 & -0.44 & 0.660 \\
\hline & $\mathrm{GDP}_{\mathrm{t}-3}$ & -0.042 & 0.020 & -2.13 & $0.033 * *$ \\
\hline & $\mathrm{GDP}_{\mathrm{t}-4}$ & 0.002 & 0.020 & 0.11 & 0.915 \\
\hline & $\mathrm{M} 2_{\mathrm{t}-1}$ & 0.008 & 0.008 & 0.94 & $0.049 * *$ \\
\hline & $\mathrm{M} 2 \mathrm{t}-2$ & 0.003 & 0.008 & 0.43 & $0.025 * *$ \\
\hline & $\mathrm{M} 2_{\mathrm{t}-3}$ & 0.007 & 0.006 & 1.11 & 0.268 \\
\hline & $\mathrm{M} 2 \mathrm{t}-4$ & 0.006 & 0.007 & 0.85 & 0.394 \\
\hline & $\mathrm{EX}_{\mathrm{t}-1}$ & 0.062 & 0.074 & 0.84 & 0.401 \\
\hline & $\mathrm{EX}_{\mathrm{t}-2}$ & 0.359 & 0.066 & 5.42 & $0.000 * * *$ \\
\hline & $\mathrm{EX}_{\mathrm{t}-3}$ & 0.114 & 0.088 & 1.29 & 0.196 \\
\hline & $\mathrm{EX}_{\mathrm{t}-4}$ & 0.169 & 0.087 & 1.93 & $0.054 * *$ \\
\hline \multirow{3}{*}{$\begin{array}{l}\text { Model } \\
\text { Diagnostic } \\
\text { test }\end{array}$} & R-Squared & \multicolumn{3}{|l|}{0.0936} & \\
\hline & Adjusted R-Squared & \multicolumn{3}{|l|}{0.0597} & \\
\hline & F-Statistic & \multicolumn{3}{|l|}{$2.7600 * *$} & \\
\hline
\end{tabular}

Figure 5. Impulse Response of SSEIDX to Innovations of Selected Macroeconomic Variables 

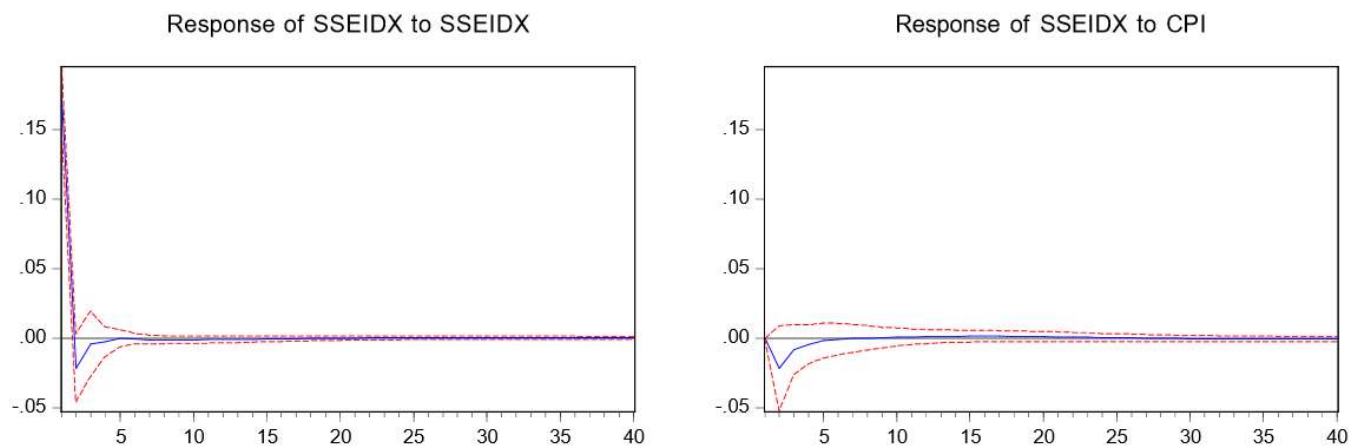

Response of SSEIDX to EX

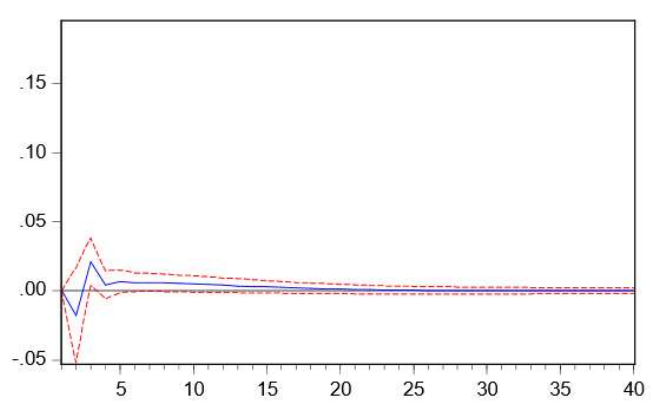

Response of SSEIDX to GDP
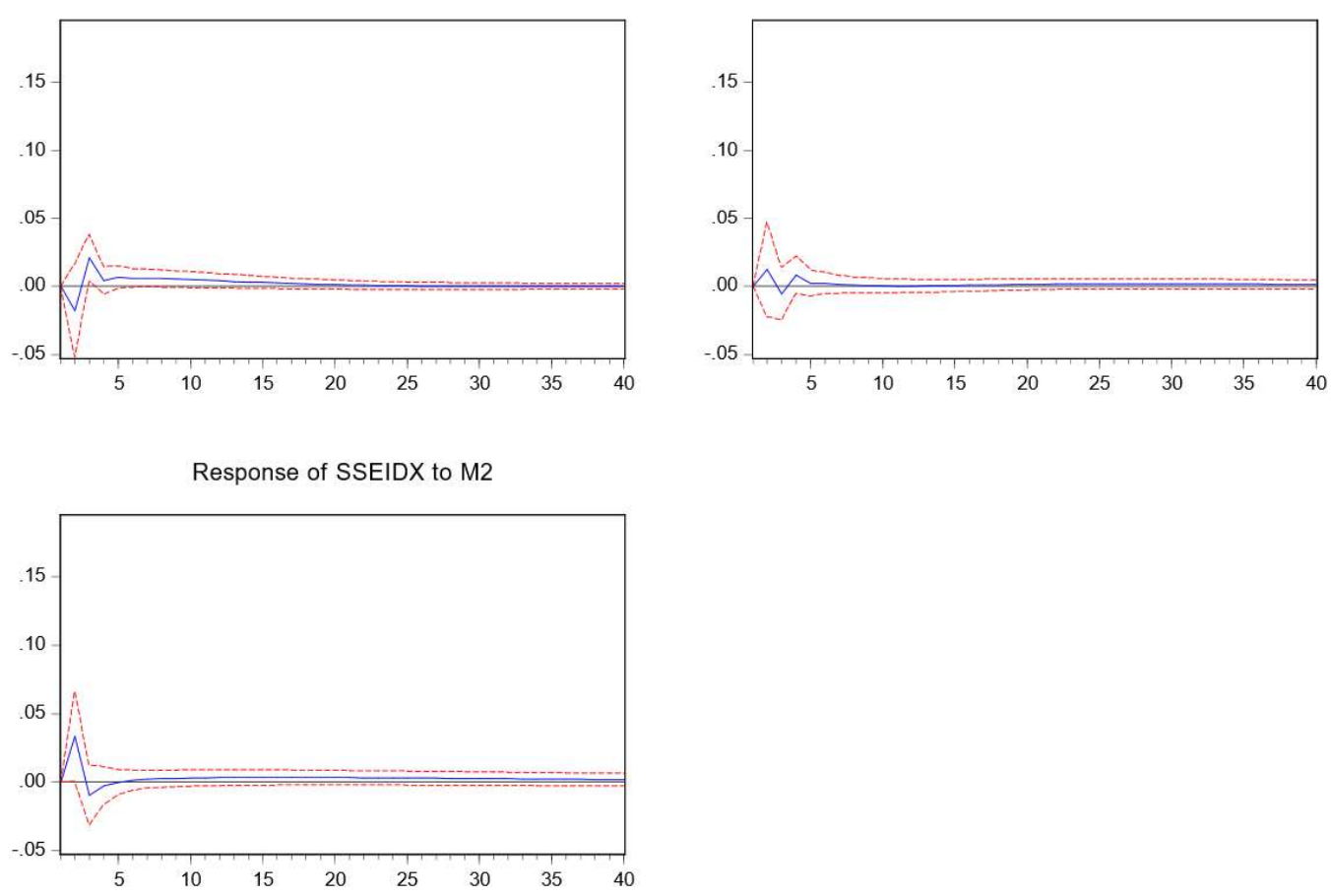

Note: The confidence bands are computed using the $95 \%$ confidence intervals. The graphs are displayed in 40 periods with three lags. 


\begin{tabular}{|c|c|c|c|c|c|}
\hline Quarters & $\Delta$ SSEIDX & $\Delta \mathrm{CPI}$ & $\Delta \mathrm{EX}$ & $\Delta$ GDP & $\Delta \mathrm{M} 2$ \\
\hline 1 & 100 & 0.00 & 0.00 & 0.00 & 0.00 \\
\hline 2 & 93.56 & 0.40 & 1.73 & 3.20 & 1.29 \\
\hline 3 & 79.94 & 2.56 & 3.84 & 5.64 & 8.02 \\
\hline 4 & 77.92 & 3.42 & 2.63 & 5.15 & 10.88 \\
\hline 5 & 76.65 & 4.02 & 2.65 & 4.61 & 12.07 \\
\hline 6 & 75.95 & 5.32 & 4.93 & 5.62 & 12.74 \\
\hline 7 & 75.38 & 4.37 & 3.75 & 4.69 & 11.81 \\
\hline 8 & 75.29 & 4.57 & 3.76 & 4.72 & 11.66 \\
\hline 9 & 75.27 & 4.71 & 3.75 & 4.75 & 11.52 \\
\hline 10 & 75.40 & 4.71 & 3.74 & 4.77 & 11.38 \\
\hline 11 & 75.32 & 4.71 & 3.74 & 4.77 & 11.46 \\
\hline 12 & 75.18 & 4.71 & 3.74 & 4.77 & 11.60 \\
\hline
\end{tabular}

Discussions and Policy Implications

This research contributes to the existing literature in three main aspects. First, this research uncovers the fact that there exists a long-run equilibrium relationship between macroeconomic variables and stock prices in the Chinese stock market. Second, the paper empirically explores the short-term dynamic relationships between selected macroeconomic variables and stock prices as follows:

* For stock prices (SSEIDX) itself, the lagged and two-lagged period of stock prices has negative influence on current period while the lagged and three lagged period of GDP also shows a significant but negative influence on current period. This may prompt investors not to base their expectations of future results on past performance. The likelihood of various stock price outcomes is hypothetical in nature and everybody should realize about the ups and downs of stock market.

* Inflation (CPI) is negatively related to stock prices in China in the short-run with an insignificant coefficient of 0.027. This means that the system corrects its previous period disequilibrium 0.027 times reflecting a less sizable speed of adjustment to reach equilibrium steady state position. A similar study for China by Zhongqiang (2014) also substantiates this outcome that inflation is weakly related to stock prices in China but its insidious effect on macro economy is evident because raising inflation surges the cost of production, and consumers can purchase fewer goods due to reduction in purchasing power, firms' revenues and profits decline resulting in firms' value and stock prices. By any stretch of imagination, monetary authority and businesses must constantly monitor inflation since if left unchecked, it could spike and would likely cause deceleration in the economy.

* The estimated value of exchange rates (Chinese yuan per USD) is 0.359 . This short run coefficient also represents the short run equilibrium. It implies the rate at which the previous period disequilibrium of the system is being corrected. Thus, the system corrects its previous period disequilibrium at a speed of 35.9 percent between exchange rates and the Chinses stock prices. This confirms findings by Hussin, Muhammad, Abu and Awang (2012), Kabir, Bashar and Masih (2014), and Jung and Tantatape (2018) whose discoveries do not delineate from the findings the present studies. During period under study, a depreciation of the Korean won makes Korean exports more competitive but raises the cost of importing goods into Korea. This results in a decline in imports and an increase in exports. Findings of this research is highly consistent since China's economy has become the world's factory and has consistently chartered the path of improving its competitive advantage of exports against import. Hence, domestic firms benefit from increased return to scale. An increase in exports raise profits and the firms' value along with stock prices. The increased demand for stocks drives prices up further when investors shift their portfolio from bonds to stocks to profit from rising stock prices. This is a whole new take that the monetary authorities of East Asian countries should care about not only the US dollar and the euro, but also the Chinese yuan, because China has a larger role in intra-regional economic relations.

Finally, there is no compelling evidence that money supply and inflation significantly affect stock price dynamics in the Chinese stock market. In light of these findings, financial managers can enhance their understanding of the short-run movements of Gross Domestic Product (GDP), exchange rates and stock price dynamics. A better understanding of these short -run and longrun movements enables financial managers to make well informed investment and financial decisions. 


\section{Conclusions}

Recommendations can be drawn from the findings presented in this paper. From a long-term perspective, policymakers should consider selected macroeconomics such as gross domestic product, money supply and exchange rates as policy tools aiming at the Chinese stock market since the results show evidence of a long-run equilibrium relationship among them. However, from a short-term perspective, policymakers may consider the inflation as policy tools to manage and control the Chinese stock market since this variable, to some extent, may cause an adverse effect on stock prices in China. This policy should be effective in the short-run then be evaluated in the future.

On the contrary, the results acknowledge that inflation exhibit no relationship on stock prices in China. It would appear that this independent behavior of the stock market could be a state of the market liberalization process for its economy to heal and propel itself toward long-run stability and a better future of the China stock market. Therefore, policymakers and investors should devote more time and effort acquiring not only the information on changes in economic policy and temporary external shocks in the short-run, but also the knowledge and information about the market itself.

Further research may be directed at some of the above issues. The empirical model may be estimated with alternative economic and financial factors or markets. Studies encompassing different economies should be conducted where data is available. Such research should contribute toward improving our understanding of the market mechanism and responses of each market to the frequently occurring phenomena of economic and financial crisis, whether regional or global.

\section{References}

1. Adam, A. M., \& Tweneboah, G. (2008). Do macroeconomic variables play any role in the stock market movement in Ghana?. Available at SSRN 1152970.

2. Chami, R., Barajas, A., Cosimano, T., Fullenkamp, C., Gapen, M., \& Montiel, P. (2008). Macroeconomic consequences of remittances (p. 259). Washington, DC: International Monetary Fund.

3. Wongbangpo, P., \& Sharma, S. C. (2002). Stock market and macroeconomic fundamental dynamic interactions: ASEAN-5 countries. Journal of asian Economics, 13(1), 27-51.

4. Levine, R. (2005). Finance and growth: theory and evidence. Handbook of economic growth, 1, 865-934.

5. Peng, J., Cui, J., Qin, F., \& Groenewold, N. (2009). Stock prices and the macro economy in China. Economics Discussion Paper no, 9.

6. Cox, J. C., \& Ross, S. A. (1976). A survey of some new results in financial option pricing theory. The Journal of Finance, 31(2), 383-402.

7. Adam, A. M., \& Tweneboah, G. (2008). Do macroeconomic variables play any role in the stock market movement in Ghana?. Available at SSRN 1152970.

8. Cheung, Y. W., \& Ng, L. K. (1998). International evidence on the stock market and aggregate economic activity. Journal of empirical finance, 5(3), 281-296.

9. Humpe, A., \& Macmillan, P. (2009). Can macroeconomic variables explain long-term stock market movements? A comparison of the US and Japan. Applied financial economics, 19(2), 111-119.

10. Kwon, C. S., \& Shin, T. S. (1999). Cointegration and causality between macroeconomic variables and stock market returns. Global finance journal, 10(1), 71-81.

11. Maysami, R. C., \& Koh, T. S. (2000). A vector error correction model of the Singapore stock market. International Review of Economics \& Finance, 9(1), 79-96.

12. Bloomberg (2020, June 18). China Signals Further Reserve Ratio Cut to Spur Bank Lending. Bloomberg News. https:/www.bloomberg.com/news/articles/2020-06-18/china-signals further-reserve-ratio-cuts-to-spur-bank-lending

13. UNCTAD (2020, January 20). Global Investment Flows Flat in 2019, Moderate Increase Expected in 2020. UNCTAD https://unctad.org/news/global-investment-flows-flat-2019-moderate-increase-expected-2020

14. Carpenter, J. N., \& Whitelaw, R. F. (2017). The development of China's stock market and stakes for the global economy.

15. Gan, C., Lee, M., Yong, H. H. A., \& Zhang, J. (2006). Macroeconomic variables and stock market interactions: New Zealand evidence. Investment management and financial innovations, (3, Iss. 4), 89-101.

16. Cheung, Y. W., \& Ng, L. K. (1998). International evidence on the stock market and aggregate economic activity. Journal of empirical finance, 5(3), 281-296.

17. Gupta, A. D., \& Padhan, P. C. (2007). The nexus between stock market and economic activity: an empirical analysis for India. International Journal of Social Economics.

18. Peng, J., Cui, J., Qin, F., \& Groenewold, N. (2009). Stock prices and the macro economy in China. Economics Discussion Paper no, 9.

19. Bai, Z. (2014). Study on the Impact of Inflation on the Stock Market in China. International Journal of Business and Social Science, 5(7), 261-271.

20. Miller, M. H. (1988). The Modigliani-Miller propositions after thirty years. Journal of Economic perspectives, 2(4), 99120.

21. Beltratti, A., \& Morana, C. (2006). Breaks and persistency: macroeconomic causes of stock market volatility. Journal of econometrics, 131(1-2), 151-177. 
22. Hondroyiannis, G., Lolos, S., \& Papapetrou, E. (2005). Financial markets and economic growth in Greece, 19861999. Journal of International Financial Markets, Institutions and Money, 15(2), 173-188.

23. Gjerde, Ø., \& Saettem, F. (1999). Causal relations among stock returns and macroeconomic variables in a small, open economy. Journal of International Financial Markets, Institutions and Money, 9(1), 61-74.

24. Chaudhuri, K., \& Smiles, S. (2004). Stock market and aggregate economic activity: evidence from Australia. Applied Financial Economics, 14(2), 121-129.

25. Hamao, Y. (1988), "An empirical investigation of the arbitrage pricing theory", Japan and the World economy, 1, 45-61.

26. Fama, E.F. and Gibbons, M. (1982), "Inflation, Real Returns and Capital Investment"

27. Journal of Monetary Economics, 1982, Vol. 9, No. 3, pp. 545-565.

28. Solnik, B., \& Solnik, V. (1997). A multi-country test of the Fisher model for stock returns. Journal of International Financial Markets, Institutions and Money, 7(4), 289-301.

29. Gan, C., Lee, M., Young, H.W.A. and Zhang, J., (2006), "Macroeconomic Variables and Stock Market Interaction: New Zealand Evidence", Investment Management and Financial Innovations, Volume 3, Issue 4

30. Chang, K. L. (2009). Do macroeconomic variables have regime-dependent effects on stock return dynamics? Evidence from the Markov regime switching model. Economic Modelling, 26(6), 1283-1299.

31. Gan, C., Lee, M., Yong, H. H. A., \& Zhang, J. (2006). Macroeconomic variables and stock market interactions: New Zealand evidence. Investment management and financial innovations, (3, Iss. 4), 89-101.

32. Özlen, S., \& Ergun, U. (2012). Macroeconomic factors and stock returns. International Journal of Academic Research in Business and Social Sciences, 2(9), 315.

33. Aweda, N. O., Are, S. O., \& Akinsanya, T. (2014). Statistically Significant Relationships between Returns on FTSE 100, S\&P 500 Market Indexes and Macroeconomic Variables with Emphasis on Unconventional Monetary Policy. International Journal of Statistics and Applications, 4(6), 249-268.

34. Tripathi, V., \& Seth, R. (2014). Stock market performance and macroeconomic factors: the study of Indian equity market. Global Business Review, 15(2), 291-316.

35. Mutuku, C. (2014). Macroeconomic variables and the Kenyan equity market: A time series analysis. Kenya Institute for Public Policy Research and Analysis (KIPPRA)

36. Lee, J. W., \& Brahmasrene, T. (2018). An exploration of dynamical relationships between macroeconomic variables and stock prices in Korea. Jung Wan Lee, Tantatape Brahmasrene/Journal of Asian Finance, Economics and Business, 5(3), 7-17.

37. Aldukhail, A. M. (2019). The effect of macroeconomic variables on the Saudi stock market. Archives of Business Research, 7(12), 126-152.

38. Bassar TS. Analysis of the effect of Sharia stock trading activity factors and macroeconomic factors on the

39. performance of Sharia Stocks in the capital market in Indonesia. International Journal of Tax Economics and Management. 2019;2(11):12-28.

40. Liu, X., \& Sinclair, P. (2008). Does the linkage between stock market performance and economic growth vary across Greater China?. Applied Economics Letters, 15(7), 505-508.

41. Adam, A. M., \& Tweneboah, G. (2008). Do macroeconomic variables play any role in the stock market movement in Ghana?. Available at SSRN 1152970.

42. Fama, E. F., \& Schwert, G. W. (1977). Asset returns and inflation. Journal of financial economics, 5(2), 115-146.

43. Dickey, D. A., \& Fuller, W. A. (1979). Distribution of the estimators for autoregressive time series with a unit root. Journal of the American statistical association, 74(366a), 427-431. 